\title{
Computer measurement of ampacity of thin layers made on textile composite substrate
}

\author{
Ewa Korzeniewska ${ }^{1, *}$, Artur Szczęsny ${ }^{1}$, Jerzy Józwik ${ }^{2}$, and Arkadiusz Tofil ${ }^{3}$ \\ ${ }^{1}$ Institute of Electrical Engineering Systems, Faculty of Electrical Engineering, Electronics, Informatics and Automatic Control, Lodz \\ University of Technology, Stefanowskiego 18/22, 90-924 Łódź, Poland \\ ${ }^{2}$ Department of Production Engineering, Lublin University of Technology, Mechanical Engineering Faculty, Nadbystrzycka 36, \\ 20-816 Lublin, Poland \\ ${ }^{3}$ The Institute of Technical Sciences and Aviation, The State School of Higher Education, Pocztowa Street 54, 22-100 Chelm, Poland
}

\begin{abstract}
Technology of creating electrical and electronic systems on flexible substrates, with special emphasis on textile substrates, is one of the most important areas in the field of developing textronics, which is applicable in protective clothes. Resistance and ampacity are the key parameters of electrically conductive thin layers formed on such substrates. Authors of this paper present the results of research related to creation of thin-layered, electrically conductive structures on substrates using a vacuum technology of layer application and assess the scope of their usefulness. Measurement of averaged surface temperature and thermal energy emitted at the surface of the structure will be the subject to metrological evaluation. The authors present developed method with Peltier cells used for measuring the average temperature and emitted heat to evaluate these parameters. The described method allows measurement of average values by matching the dimensions of the cell to the surface. The proposed method avoids possible temperature gradient around the point of measure which occurs in contact methods. The test results also pertain to the determination of the resistance of the test surfaces using a balance of generated thermal power which allows evaluation of the process of creating layers.
\end{abstract}

\section{Introduction}

Textronics is a field of knowledge, which was established on the basis of such scientific areas as electronics, textiles and information technology, with the use of knowledge in the area of automation and metrology. Many research studies in the field of textronics focus on the introduction of electrical circuits and electrically conductive elements into the textile structures so as to the resulting products are visually similar to the currently used products deprived of their textronic properties. Steady progress in the fields of optimisation $[1,2]$ and miniaturisation of microelectronics and the development of new technology allow to integrate functional clothing, enabling completely new applications.

Thin electroconductive layers formed on flexible substrates may be connected to cloths and used as an integral part of textronic systems used among others in medicine for measurement and monitoring body parameters [3-8]. It is also particularly important when textronic structures are a component of sensors monitoring the working conditions for example humidity or gas sensors $[9,10]$. Before smart textiles, in which the textronic systems are used, high requirements are, on the one hand, connected to the correct structure and, on the other hand, connected to miniaturisation of applied electronics and precision recording and data processing. Therefore, it is important to define their basic parameters, which include ampacity and resistance of the created surface. It determines the designation of the rated current of the layer and in the same time the determination of the current value, which will cause irreparable destruction of the current path. Processes occurring at time of the textronic structure destruction may be a direct or indirect threat to life and health by changing the operating parameters of the electrical circuit [11].

\section{Subject and methods}

\subsection{The electroconductive thin layers on composite substrates}

The textile substrate is a collection of textile fibres arranged in a regular or chaotic way forming a porous spatial structure. The deposited electroconductive material on this kind of substrate penetrates the backing into a greater or lesser extent. Production of thin electroconductive layer on this type of textile structure is a complex process, and the effect of the current conductivity is difficult to achieve. The prepared samples with metal layer were rectangular and they suited to the dimension of the used Peltier cell during measurement process. The metal layer created during the

${ }^{*}$ Corresponding author: ewa.korzeniewska@p.lodz.pl 
research on the textile substrate is characterised by local discontinuities. However, a layer with good electrical properties is possible to be achieved. Its resistance measured by the four-probe electrode system is less than $1 \Omega / \mathrm{m}^{2}[11,12]$. This kind of measurement method is commonly used also in other area of research [13]. It is also the most suitable method for resistance measuring of prepared geometry samples. Thickness of the created layers is about $300 \mathrm{~nm}$, and because the substrate is very flexibly it was measured in indirect method. The microscopic images of metallic layers on the textile substrate is shown in Figure 1a, and on the composite substrate in Figure 1b. These photos were taken using a scanning electron microscope SEM Hitachi S-4200.

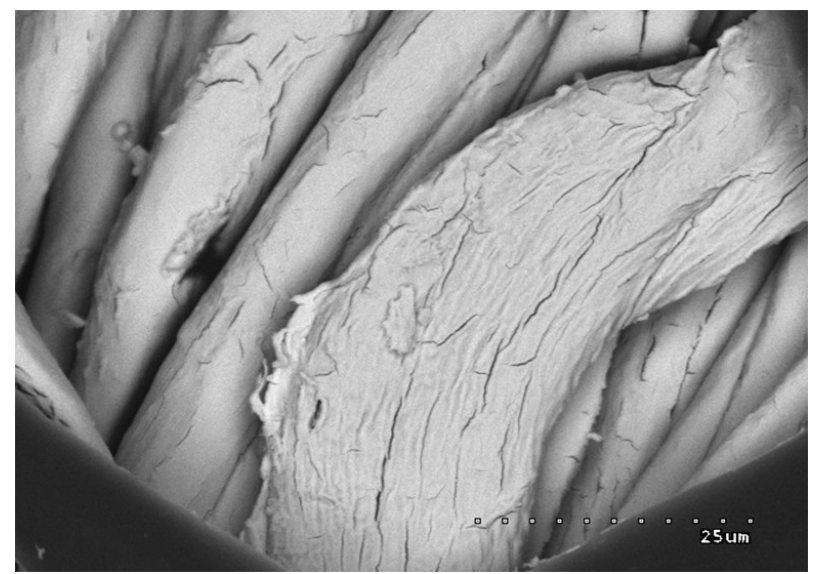

a)

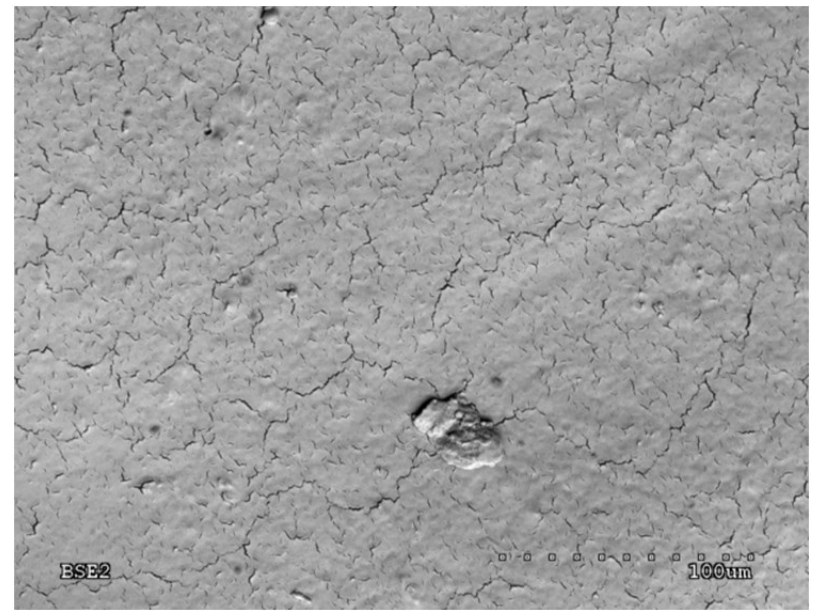

b)

Fig. 1. The microscopic images of metallic layer formed: a) on a textile structure and b) on a composite structure.

As it can be seen in Figure 1a it is difficult to achieve continuous metallic layer on the typical textile substrate because the textile structure is a collection of threads which are deformed during use. Additionally, the threads have porous structure, consisting of single fibres. Because of the connection of the threads, conductive layer deposited on the fabric surface penetrates into greater or lesser extent due to the porosity of the substrate.
Figure $1 \mathrm{~b}$ presents the microscopic image of metallic layer formed on a composite textile. The formed metallic layer has many micro cracks but although the thin film is interrupted in many places, owing to the fact that the substrate is homogenous and uninterrupted on the surface, it is much easier to achieve good electrical properties of the coating. Despite the careful substrate surface cleaning before the metal layer application it is possible to keep contamination which can also be seen in Figure $1 \mathrm{~b}$.

Due to the newly created field of science which is textronics, in contrast to the developed research on surface engineering of thick-layer structures [14,15]. protection of textronic structures against destruction and deformations requires a wide spectrum of research.

During the research the thin conductive layer is formed in the physical vapour deposition (PVD) process using the Classic 250 Pfeiffer Vacuum System. Silver with a purity of $99.99 \%$ is deposited metal and it is evaporated from the resistance source. The deposition time is five minutes after the achieving $2 \cdot 10^{-5}$ mbar prevacuum.

Silver was deposited on the surface of the elastic composite structure made of nylon threads covered with a polyurethane film. This material is available under the trade name Cordura. This kind of substrate makes the protective clothes more durable.

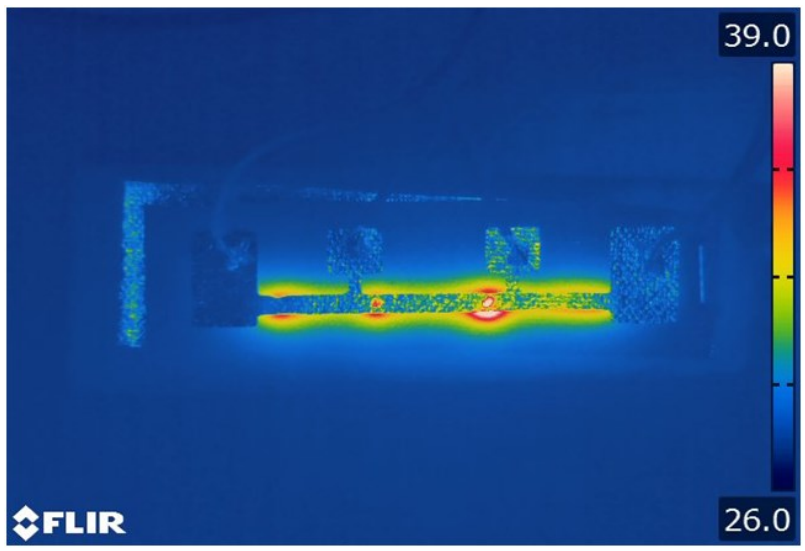

a)

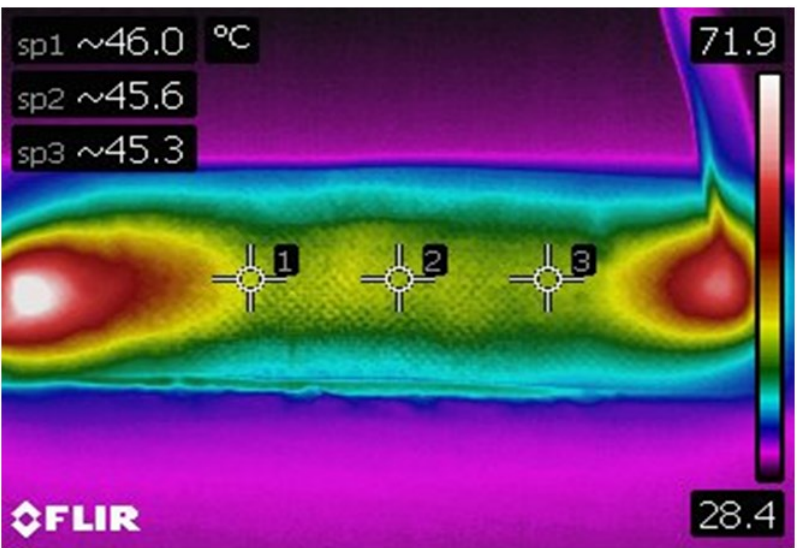

b)

Fig. 2. The thermograms of the thin a) defective

b) homogeneous $\mathrm{Ag}$ layer formed on a substrate composite. 


\section{Results}

In order to evaluate the ampacity, the thermal resistance of the sample as the resistance of an electroconductive layer - environment was calculated.

The thermal Ohm's law (1) was used to determine the thermal resistance of the sample [16-18]

where:

$$
\Delta T=P_{x} \cdot R_{t h}
$$

$\Delta T$ - the temperature difference between the Ag layer on the composite substrate and the environment;

$\mathrm{P}_{\mathrm{x}}$ - input power from the power source, which is connected to the layer;

$\mathrm{R}_{\text {th }}$ - thermal resistance of the Ag layer created on the composite substrate can be calculated according to formula (2)

$$
R_{\operatorname{th} A g}=\frac{P_{x}}{\tau_{0}-\tau_{l}}
$$

$\mathrm{T}_{\mathrm{o}}$ - room temperature

$\mathrm{T}_{1}$ - temperature of Ag layer

The thermal resistance of created layer on the composite substrate, calculated with the formula (2), is $\mathrm{R}_{\text {th } \mathrm{Ag}}=80 \mathrm{~mW} /{ }^{\circ} \mathrm{C}$ which recalculated per $\mathrm{m}^{2}$ equals $\mathrm{R}_{\text {th Ag }} / \mathrm{m}^{2}=18 \mathrm{~mW} /\left({ }^{\circ} \mathrm{C} \mathrm{m}^{2}\right)$.

Results of the temperature dependence of Ag structure on a composite substrate on the power consumed from the power supply are shown in Figure 3.

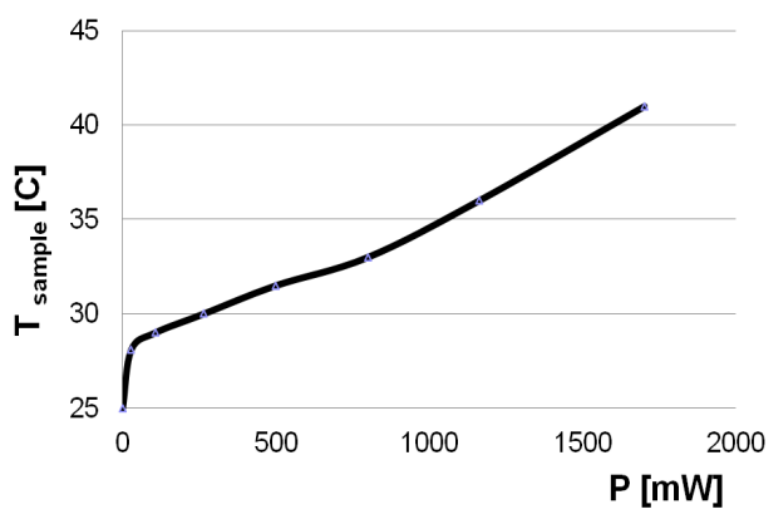

a)

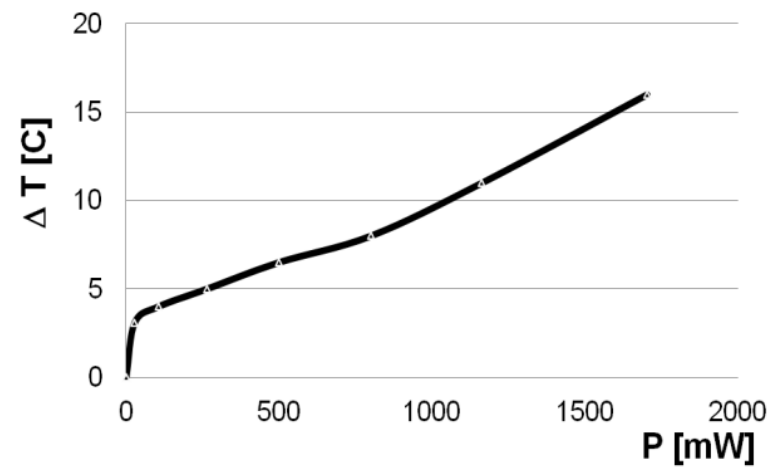

b)

Fig. 3. The dependence of:

a) the temperature of the $\mathrm{Ag}$ thin layer on a composite substrate b) the temperature difference between the thin layer and the environment on the power consumed from the power source.
The Peltier cell was used to determine the average temperature of electroconductive layer. The measurements of the dependence of the voltage on the Peltier cell on power absorbed from the power source was made (Fig. 4). The measurement system is isolated from the environment. The photo of the used measurement stand is presented in Figure 5. Heat transfer takes place in the area of the connection between the layer and the cell. It can be observed on the thermogram which is shown in Figure 6.

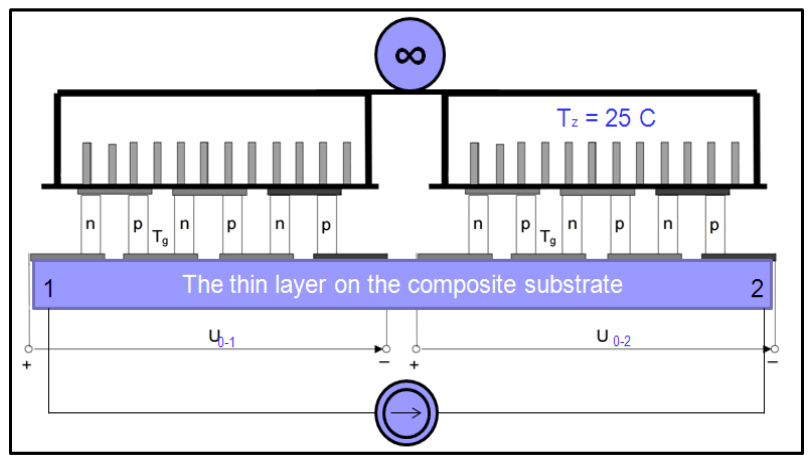

Fig. 4. The block diagram for measuring the dependence of the Peltier voltage on power absorbed by the thin Ag layer.

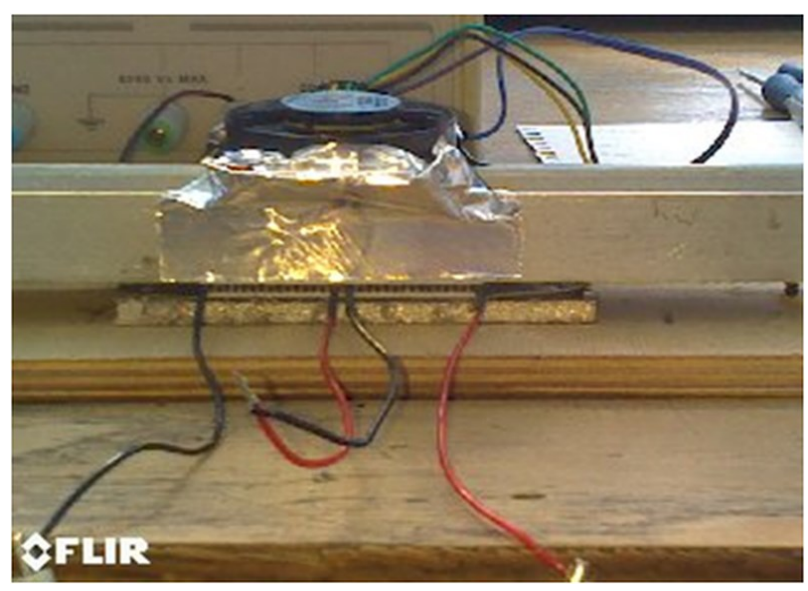

Fig. 5. The photo of the measurement stand.

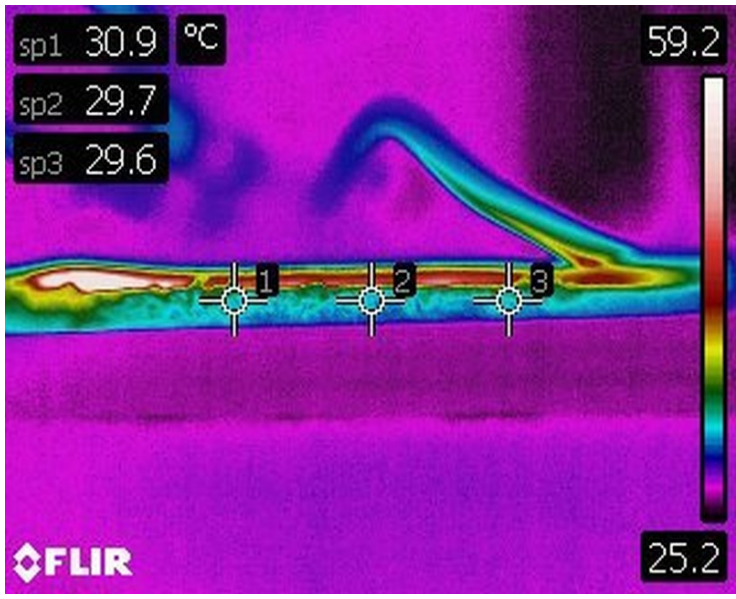

Fig. 6. The thermogram of the background of the sample. 
Figure 4 shows the block diagram for measuring the dependence of the Peltier voltage on power absorbed by the thin Ag layer. The observed temperature distribution shows that the conduction of heat from the sample takes place primarily between the deposited silver conductive layer and the environment. By dint of the special design of the substrate the heat does not penetrate into it, and the heat exchange with the environment is carried out by heat in a sample-Peltier system and free convection with the environment. The measured dependence is shown in Figure 7. As the result of comparison of the slots which are shown in Figure 3 and 7, it is possible to estimate the average temperature of the sample depending on the measured the Peltier voltage. This relationship is shown in Figure 8.

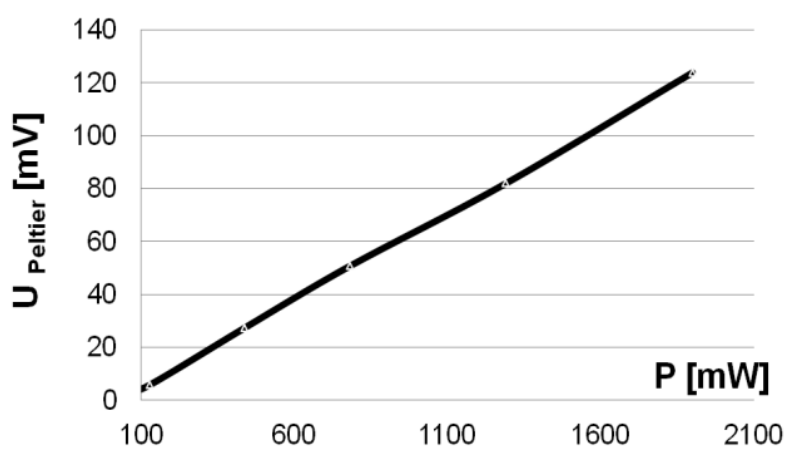

Fig. 7. The dependence of the Peltier voltage on the power absorbed from the power source through the electro-conductive thin layer.

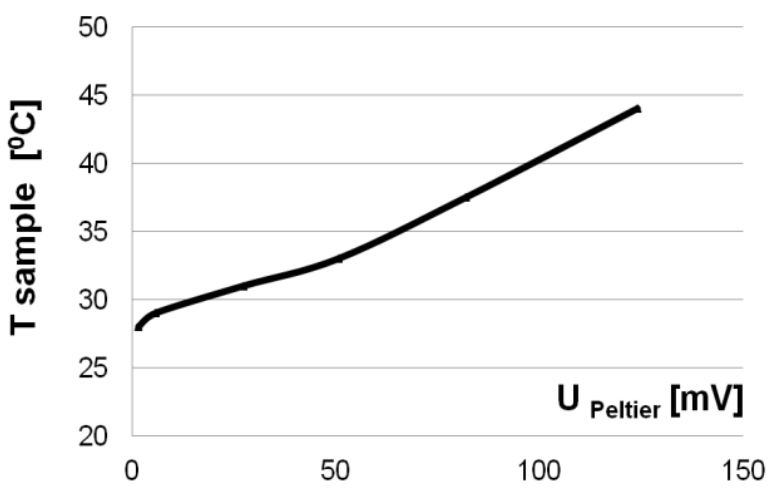

Fig. 8 Temperature dependence of the Ag layer created on the composite substrate on the Peltier voltage.

The ability of determining the average temperature of the sample surface on the basis of the measured voltage on the Peltier cell applied to the thin metallic layer is the result of analysis of the characteristics shown in Fig. 8.

where:

$$
T_{a v}=\alpha \cdot U_{p}+T_{0}
$$

$\mathrm{T}_{\mathrm{av}}$ - average temperature of the sample surface

$\mathrm{U}_{\mathrm{p}}-$ measured voltage on the Peltier cell

$\mathrm{T}_{\mathrm{o}}$ - ambient temperature

$\alpha$ - coefficient of temperature changes on the Peltier voltage
For the test composite material and applied thin silver layer the temperature change coefficient on the Peltier voltage - $\alpha$ was determined using computer software. The coefficient is dependent both on the material which was used as the layer substrate and on the material deposited in the vacuum deposition as an electro-conductive thin layer. For Cordura, as the material of the substrate and for thin silver layer created on the substrate, the coefficient $\alpha$ equals $0.13{ }^{\circ} \mathrm{C} / \mathrm{mV}$.

Experimental studies on the ampacity for the created thin silver layer on the composite substrate have been carried out. The sample was connected to a source of DC voltage of $3 \mathrm{~V}$, the source power was $9 \mathrm{~W}$. After a period of 10 minutes, the temperature of the sample was measured. The results are shown in the thermogram in Figure 9. The sample temperature was above $100^{\circ} \mathrm{C}$. The path has not been destroyed. The calculated value of current ampacity of thin Ag layer created on the composite substrate measurement process was about $3 \cdot 10^{9} \mathrm{~A} / \mathrm{m}^{2}$. The presented case is representative for a series of 50 tests.

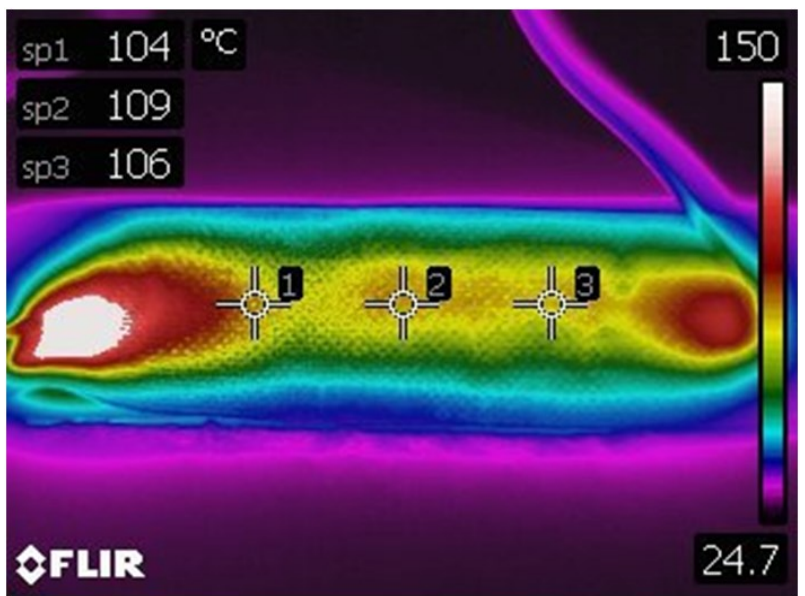

Fig. 9. The thermogram of thin $A g$ layer $(U p=3 V, I p=3 A)$.

\subsection{Thermal imaging research}

In order to evaluate the thermal emission uniformity and homogeneity of the layer, $300 \mathrm{~mA}$ current was forced through the created electro-conductive layer and thermal tests were carried out using a FLIR 60 thermal imaging camera and dedicated software.

Examples of obtained thermal images are shown in Figures 2 and 9. As it could be seen during the analysis of thermal images the conductive layers heat up unevenly. This may either be due to the heterogeneity of the metal layer applied to the substrate composite as well as the occurrence of defects in the layer structure [19, 20]. The microcracks can be observed also using other technologies such as i.e. tomography [21-23].

The analysis of thermogram shown in Figure $2 b$ shows that the difference in temperatures of the thin layer may be as high as about $40^{\circ} \mathrm{C}$. The area of current electrodes warms up the most. The electrodes make the connection to the power system. Due to the textronic application of layers it is appropriate to determine the average temperature of the entire surface of the electrically conductive path and its thermal resistance. 


\section{Discussion}

The thermal resistance $R_{\text {th }}$ calculated on the basis of measurements allows to estimate heat given off by the material-created layer system into the environment, so it is also possible linking the load thermal rating of sample under different environmental conditions. The ampacity for thin electro-conductive paths, which are used as textronic system components, may be determined on the basis of the measured average temperature of conductive layer, as the noticeable one by user of such elements. This temperature can be estimated on the basis of the acquired voltage on the Peltier cell. The measured current ampacity of the thin Ag layer formed on Cordura substrate is very high however lower than obtained in nanotubes [24- 26], which are also used in textronics and used in the process of miniaturising the electronic equipment. The authors also revealed that the measurement accuracy of the used thermal system allows to evaluate the suitability of the Peltier cells to determine the average surface temperature of the material.

\section{Conclusions}

According to the conducted tests, the ampacity of thin $\mathrm{Ag}$ layers made in the PVD method equals to $3 \cdot 10^{9} \mathrm{~A} / \mathrm{m}^{2}$. The obtained value is the result of the measurement of indirect average surface temperature and thermal energy emitted on the surface of used Peltier cells and analytical calculations. The thermal resistance of created layer on the composite substrate (Cordura) is $\mathrm{R}_{\text {th } \mathrm{Ag}}=80 \mathrm{~mW} /{ }^{\circ} \mathrm{C}$ which recalculated per $\mathrm{m}^{2}$ equals $\mathrm{R}_{\text {th Ag }} / \mathrm{m}^{2}=18 \mathrm{~mW} /\left({ }^{\circ} \mathrm{C} \mathrm{m}^{2}\right)$.

\section{References}

1. L. Kasprzyk, A. Tomczewski, K. Bednarek, Przeglad Elektrotechniczny, 87(12), 82-85 (2011).

2. L. Kasprzyk, K. Bednarek, Przeglad Elektrotechniczny, 85(12), 65-68 (2009).

3. E. Skrzetuska Przeglad Elektrotechniczny 90(4), 3440 (2014):

4. W. Bendkowska Przegląd Włókienniczy 8 (2002):

5. J. Zieba, M. Frydrysiak, M. Tokarska, Fibres \& Textiles in Eastern Europe, 19 (5), 70-74 (2011)

6. J. Zieba, M. Frydrysiak, K. Gniotek Fibres \& Textiles in Eastern Europe 15 (5-6), 105-108 (2007):

7. L. Borowik, A. Jakubas, Przeglad Elektrotechniczny 91 (1), 115-117 (2015)
8. A. Jakubas, E. Lada-Tondyra The Journal of The Textile Institute doi.org/10.1080/00405000.2017.1422308

9. M. Frydrysiak, E. Korzeniewska, Ł. Tesiorowski Sensor Letters 13(11), 998-1001 (2015)

10. Z. Stempien, M. Kozicki, R. Pawlak, E. Korzeniewska, G. Owczarek, A. Poscik, D. Sajna Proceedings of IEEE Sensors, no 7808457 (2016)

11. E. Korzeniewska, A. Jakubas Przeglad Elektrotechniczny, 12, 233-236 (2014)

12. A. Jakubas, P. Jabłonski, Measurement, 108, 34-40, (2017) doi.org/10.1016/j.measurement.2017.05.006

13. R. Pawlak, M. Lebioda, J. Rymaszewski, W. Szymanski, L. Kołodzieczyk, P. Kula, Sensors 17 (1) article number: 51( 2017)

14. J. Józwik, P. Pieśko, G. Krajewski Eksploatacja $i$ Niezawodność - Maintenance and Reliability 47 (3) 10-20 (2010)

15. J. Józwik, M. Czwarnowski Advances in Science and Technology Research Journal 28 (9) 89-95 (2015)

16. J. Hauser Przeglad Elektrotechniczny 3 42-46 (2007)

17. S. Wiśniewski, T. S. Wiśniewski WNT (2013):

18. A. Kmieć Oficyna Wydawnicza Politechniki Wrocławskiej, Wrocław (2005):

19. E. Korzeniewska International Conference on Modern Electrical and Energy Systems (MEES) 396 - 399 article no: 8248942 (2017):

20. E. Korzeniewska, J. Józwik, R. Zawiślak, A. Krawczyk, J. Michałowska Przeglad Elektrotechniczny 93(12) 111-114 (2017)

21. T. Rymarczyk; P. Adamkiewicz, J. Sikora, Przeglad elektrotechniczny, 94 (1), 93-96 (2018).

22. T. Rymarczyk; J. Szumowski, P. Adamkiewicz, P. Tchórzewski, J. Sikora, Przeglad elektrotechniczny, 94 (1) 97-100 (2018).

23. E. Gliścińska, D. Sankowski, I. Krucińska, J. Gocławski, M. Michalak, Z. Rowińska, J. SekulskaNalewajko Polymer Testing, 63 (2017) 194-203.

24. Z. Kolacinski, Ł. Szymanski, G. Raniszewski, S. Wiak Przeglad Elektrotechniczny 88 (10b) 149-152 (2012)

25. X. Wang, N. Behabtu, C. C. Young, D. E. Tsentalovich, M. Pasquali, J. Kono Advanced Functional Materials 24 (21) 3241-3249 (2014)

26. F. Brunbauer, E. Bertagnolli, J. Majer, A. Lugstein, A. Lugstein, (2016) Nanotechnology 27(38):385704 